\title{
THE PROPER STRUCTURE OF A BIOSAFETY SYSTEM AS A WAY OF REDUCING THE VULNERABILITY OF A SOCIETY, ECONOMY OR STATE IN THE FACE OF A BIOGENIC THREAT
}

\author{
Gushchin VA ${ }^{1,2} \otimes$, Manuilov VA ${ }^{3}$, Makarov VW ${ }^{4}$, Tkachuk AP ${ }^{3}$ \\ 'Laboratory of Population Variability Mechanisms in Pathogenic Microorganisms, \\ Gamaleya Research Institute of Epidemiology and Microbiology, Moscow \\ ${ }^{2}$ Department of Virology, Faculty of Biology, Lomonosov Moscow State University, Moscow \\ ${ }^{3}$ Laboratory of Translational Medicine, Gamaleya Research Institute of Epidemiology and Microbiology, Moscow \\ ${ }^{4}$ Center for Strategic Planning of the Ministry of Health of the Russian Federation, Moscow
}

To understand how vulnerable are a society, an economy and a state in the face of a biohazard, one should attempt to identify any potential holes in the national biosafety system, such as the lack of important components or technologies for biological monitoring and the inadequacy of existing analytical methods used to prevent or counteract biogenic threats. In Russia, biological monitoring is quite advanced. However, the agencies that ensure proper functioning of its components lack collaboration and do not form a well-coordinated network. Each of such agencies alone cannot provide comprehensive information on the subject. In the Russian Federation, there are at least 4 state-funded programs that collect epidemiological data and are quite efficient in performing the narrow task of monitoring infections. But because there is no central database where epidemiological data can be channeled and subsequently shared, these agencies do not complete each other. This leaves the Russian society, economy and state vulnerable to biogenic threats. We need an adequately organized, modern, fully functional and effective system for monitoring biohazards that will serve as a basis for the national biosafety system and also a tool for the identification and elimination of its weaknesses.

Keywords: biological safety, biological monitoring, pathogens

Funding: this work was supported by the Ministry of Health of the Russian Federation as part of the project The National System for Chemical and Biological Security of the Russian Federation (2015-2020) and by the Ministry of Education and Science as part of the project RFMEFI60117X0018.

$\triangle$ Correspondence should be addressed: Vladimir A. Gushchin

Gamalei 18, Moscow, 123098; wowaniada@gmail.com

Received: 30.09.2018 Accepted: 14.10.2018

DOI: 10.24075/brsmu.2018.054

\section{НАДЛЕЖАЩАЯ ОРГАНИЗАЦИЯ СИСТЕМЫ БИОБЕЗОПАСНОСТИ КАК СРЕДСТВО СНИЖЕНИЯ УЯЗВИМОСТИ ОБЩЕСТВА, ЭКОНОМИКИ И ГОСУДАРСТВА ПЕРЕД БИОГЕННЫМИ УГРОЗАМИ}

\author{
В. А. Гущин ${ }^{1,2} 凶$, В. А. Мануйлов ${ }^{3}$, В. В. Макаров ${ }^{4}$, А. П. Ткачук ${ }^{3}$ \\ Лаборатория механизмов популяционной изменчивости патогенных микроорганизмов, \\ Национальный исследовательский центр эпидемиологии и микробиологии имени Н. Ф. Гамалеи, Москва \\ 2 Кафедра вирусологии, биологический факультет, Московский государственный университет имени М. В. Ломоносова, Москва \\ з Лаборатория трансляционной биомедицины, Национальный исследовательский центр эпидемиологии и микробиологии имени Н. Ф. Гамалеи, Москва \\ ${ }^{4}$ ФГБУ Центр стратегического планирования Министерства здравоохранения России, Москва
}

\begin{abstract}
Оценка потенциальной уязвимости общества, экономики и государства перед биогенными угрозами сводится прежде всего к поиску слабых звеньев существующей системы обеспечения биологической безопасности государства. К ним можно отнести как отсутствие отдельных элементов и технических средств мониторинга биологических рисков, так и недостаточность имеющихся аналитических средств для принятия своевременных мер по предупреждению биологических угроз или устранению их последствий. В целом действующие на сегодняшний день в России системы мониторинга биологических угроз достаточно хорошо развиты. Однако их отдельные элементы, во-первых, ведомственно разобщены, что не позволяет создать единую систему с общей координацией, а во-вторых, ни один из них по отдельности не дает результатов, соответствующих всем требованиям, предъявляемым к такой информации. Так, в России действуют, как минимум, четыре отдельные государственные системы сбора информации по эпидемической и эпидемиологической ситуации, которые с должной эффективностью решают узкие задачи по инфекционному мониторингу, но, к сожалению, не способны дополнять друг друга из-за отсутствия единого аналитического центра с доступом ко всем данным. На сегодняшний день отсутствие единого мониторингового центра в области биологической безопасности является фактором потенциально высокой уязвимости общества, экономики и государства перед лицом биогенных угроз. Необходима надлежащая организация современной полнофункциональной и эффективной национальной системы мониторинга биологических угроз как основа для функционирования общенациональной службы обеспечения биологической безопасности и одновременно как средство для идентификации и устранения собственных уязвимых элементов такой государственной структуры.
\end{abstract}

Ключевые слова: биологическая безопасность, мониторинг биологических угроз, патогенные микроорганизмы

Финансирование: статья подготовлена при поддержке Министерства здравоохранения Российской Федерации в рамках программы «Национальная система химической и биологической безопасности 2015-2020» и Министерства образования и науки РФ в рамках проекта RFMEFI60117X0018.

Для корреспонденции: Владимир Алексеевич Гущин ул. Гамалеи, д. 18, г. Москва, 123098; wowaniada@gmail.com

Статья получена: 30.09.2018 Статья принята к печати: 14.10.2018

DOI: $10.24075 /$ vrgmu.2018.054 


\section{Importance of biological surveillance}

The terms «biological security» and «biological safety» encompass the entire field of human epidemiological surveillance, animal, plant and environmental health control, and countermeasures to prevent and respond to biological emergencies. A situation is classified as an emergency when it has such a strong negative impact on the normal activities of the population that it can be likened to a national or international security threat $[1,2]$. Another two important concepts used in this review are a biological (biogenic) risk, which is a probability of damage (of different severity or scope) to human health and/ or the environment caused by a biohazard, and a biological threat defined as an unacceptable biological risk [1]. Therefore, a biological threat is an emergency.

Biohazards that pose a threat to national or international security are very diverse. Biological risks originate from an intrinsic ability of all biopathogens (BPs), i.e. bacteria, viruses, toxins, prions, and protozoa, to be virulent to humans, agricultural animals and plants. In spite of the advances in healthcare both in Russia and abroad, infectious diseases still remain the primary cause of disabilities and mortality. According to expert estimates, in 2017 the Russian economy suffered a loss of over 627 billion rubles caused by only 32 most common infections [3]. Importantly, it is not the extraordinary outbreaks of emerging or imported infections that contribute the most to morbidity and economic damage but traditional seasonal endemic diseases, including ARI, flu, acute intestinal infections, chickenpox, HIV, and viral hepatitis [3].

Infection control includes such well-known and actively exploited countermeasures as vaccination, timely diagnosis, antiviral and antibacterial therapies, wide promotion of hygiene awareness, update of antiseptic techniques, countering of epidemiological risk factors, and eventually improvement of the economic and social well-being of the population [4]. However, due to the biological nature of infections, the positive effect of such countermeasures rapidly declines as pathogens evolve and evade these new traps of natural selection [5]. This process has a few important consequences. Pathogenic strains responsible for seasonal and/or epidemic respiratory and alimentary infections regularly «update» their genotypes and serotypes; infections start to manifest through similar symptoms and epidemics unfold in similar patterns even if caused by the representatives of different taxa with different resistance to treatment and prophylaxis; pathogens acquire drug-resistance and spread undeterred by immunization and undetected by standard diagnostic techniques; new mutant strains that have never circulated in the human population before arrive from their natural reservoirs. In the backdrop of the varying efficacy and availability of vaccines depending on the area of residence, age or social status of the population, the evolution of pathogens can complicate the epidemiological situation. All factors of epidemiological risk need to be thoroughly studied and timely monitored to prevent epidemics, i.e. transformation of a biological risk into a real threat [6]. State-funded agencies that provide and oversee healthcare services must have an effective tool at their disposal to coordinate epidemiological surveillance and predict epidemiological trends.

The need for an integrated national center for biological surveillance aimed at preventing biological threats is articulated in the strategy documents of the Russian Government and current federal laws and regulations [1, 7-9]. Specifically, the Basic Principles of the State Policy Ensuring Chemical and Biological Safety and Security in the Russian Federation until 2025 and beyond [8] define biological surveillance and resource provision for its implementation as top-priority tasks faced by the national system of biosafety and biosecurity. The National Security Strategy of the Russian Federation published in 2015 [9] instructs state agencies and local authorities to cooperate with civil society organizations in order to promote and enhance biological surveillance in the Russian Federation.

The authors of this article consider it necessary to give recommendations regarding the organization of a joined coordinating center [10] for inter-agency cooperation in order to prevent duplication of the existing systems of national epidemiological surveillance today, since, as noted above, vulnerabilities in the biological security system can be directly equated to the vulnerabilities of the entire state and society.

\section{Russia needs an integrated national system for biological surveillance}

In Russia, federal agencies normally employ 4 major methods for collecting epidemiological and epidemic data. Each of them is used to solve a narrow range of tasks pertaining to biosurveillance, including:

- analysis of incidence of the most prevalent infections;

- investigation of disease outbreaks;

- control of infectious hazards posed by the environment and consumer goods;

- study of the local incidence of major diseases that have a significant impact on the society and the effects of epidemiological factors on the subpopulations at risk;

- study and prediction of seasonal and periodic strains of some epidemic infections.

Let us take a closer look at these methods.

1. The incidence of the most common infections is analyzed by Rospotrebnadzor (the Russian Federal Service for Surveillance of Consumer Rights Protection and Human Wellbeing) [11]. Information is collected by regional and municipal healthcare facilities (HCF). Once a patient has been diagnosed with an infection, the doctor fills out a report form and forwards it to a regional office of Rospotrebnadzor [12]. Rospotrebnadzor collects and processes the received data and then publishes an annual report. An undisputable advantage of this method of data collection is wide population coverage in all Russian regions: it keeps account of all infected patients who present to hospital. It also involves quite a few HCFs creating a stable network that continuously supplies new data to the head agency. The homogeneity of the collected data is ensured by the uniformity of reporting.

Considering the definition of incidence, which is a ratio of new cases of the disease to the annual average population size [13], this method of data collection accounts for only officially diagnosed cases of infection among self-referred patients. Individuals with asymptomatic chronic infections who choose not to consult a doctor or those misdiagnosed and therefore contagious are not reported. This renders the collected information somewhat irrelevant since it cannot be used to reliably estimate the prevalence of infection in the general population. In most cases, HCFs do not have the necessary equipment to identify a pathogen down to the strain level, especially when it comes to respiratory and acute intestinal infections. Therefore, etiologically, epidemiologically and biologically different infections that demand different prevention measures and different treatment regimens are reported as if they were the same, i.e. their incidence is estimated unreliably.

In this regard, the creation of a joined monitoring center will help overcome above mentioned shortcomings while observing the necessary principles for monitoring. At the same time, 
such a center should not duplicate the functions of the listed agencies (such as morbidity analysis, outbreak investigation and product safety analysis, scientific epidemiological studies in risk groups) [6].

2. At the state level, epidemiological surveillance and sanitary control [14] are performed by the regional and federal centers for hygiene and epidemiology $(\mathrm{CHE})$ of Rospotrebnadzor $[11,15]$. Their duties include scheduled and surprise inspections of water, consumer goods, land reserves and other environmental objects for the presence of BPs included in the officially approved list, the majority of which persist in natural reservoirs, cause acute intestinal infections and helminthiases [16-18]. Another area of CHE expertise is investigation of infection outbreaks [13].

Control of animal infections including those posing a threat to humans is executed by regional and interregional veterinary laboratories of the Federal Service for Veterinary and Phytosanitary Surveillance. However, the agency does not share the obtained information with other healthcare services.

$\mathrm{CHE}$ owns an extensive network of laboratories across Russia equipped with state-of-the-art high-performance diagnostic tools for effective and continuous routine epidemiological surveillance, accurate identification of BP etiology, prompt reporting of imported BPs, causative agents of epidemic and highly dangerous infections or those persisting in natural reservoirs, and tracking their spread during the outbreak.

At the same time, routine duties of Rozpotrebnadzor normally include surveillance of a narrow range of BPs $[16,17]$ using specific tools for their detection [18] that covers only a few typical niches, preventing the real incidence of infections (even those from the list) from being unveiled and the actual vulnerability of the population in the face of these infections from being accurately estimated.

Executive bodies of Rospotrebnadzor have sufficient experience and efficient tools to detect causative agents of alimentary and zoonotic infections, as well as those persisting in natural reservoirs, and to investigate their outbreaks. Still, they hardly ever engage in the surveillance of parenteral and respiratory infections with epidemic potential although the economic and social damage caused by the latter exceeds the damage inflicted by the outbreaks of relatively rare infections [3].

On the whole, the existing system of epidemiological surveillance and sanitary control successfully solves vital yet narrow practical tasks that bear only partial relevance to the mission of epidemiological surveillance in Russia.

3. Epidemiological research into a narrow range of BPs afflicting some social groups or occurring in certain geographical locations is carried out by state research institutions supervised by Rospotrebnadzor, the Ministry of Health and the Ministry of Education and Science of the Russian Federation. These research studies are usually ordered by the state as part of what was formerly known as federal targeted programs or are initiated by the institution itself provided it has sufficient funds to sponsor the study. As a rule, research institutions are not expected to perform epidemiological surveillance and collect statistics on a regular basis. Still, some of them have transformed into centers for pathogen control, like the Federal Research and Methodological Center for AIDS Prevention and Control at the Central Research Institute of Epidemiology, WHO Collaborating Center for Influenza at the State Research Center of Virology and Biotechnology VECTOR, or the National Research and Methodological Center for Measles and Rubella at Gabrichevsky Institute for Epidemiology and Microbiology, and have their own diagnostic laboratories. Such centers share information about seasonal strains and serotypes of some BPs (including the influenza virus) essential for elaborating adequate prevention strategies.

These centers use advanced technologies in their work ensuring high sensitivity and specificity of detection and identification of various BPs and strictly adhere to the rules of good epidemiological practice. As a result, they can reliably estimate the actual incidence of a pathogen in a certain subpopulation at risk or in a reference group.

However, research institutions do not conduct large-scale epidemiological studies nor do they engage in small-scale studies on a regular basis in the absence of adequate funding. Besides, they only deal with their "specialty" pathogens. In addition, their findings are presented as articles in academic journals or similar literature sources, or as reports that do not comply with a format of a statistical report and therefore cannot be readily pasted into official papers, given the lack of interagency coordination.

4. Healthcare and sanitary services also gather data on disease incidence in different subpopulations, including information about the contamination of environmental objects. Among them are the Federal Security Service of the Russian Federation, the Ministry of Defense, the Federal Customs Service, the Federal Medical and Biological Agency (FMBA), the Ministry of Civil Defense, Emergencies and Disaster Relief, the Ministry of Transport, etc. However, the information they obtain is intended for internal use only and to our knowledge is not factored into public health strategies. So, these bodies do not participate in epidemiological surveillance (at least in times of peace).

To sum up, in Russia certain components of epidemiological surveillance of infectious diseases are relatively advanced (Fig. 1) but do not form a well-coordinated network due to the lack of collaboration between the involved agencies in the first place. Secondly, the collected information does not satisfy strict quality and quantity criteria: it cannot be extrapolated to the general population, it lacks important information about the etiology of pathogens and the rate of data collection is quite slow. The most important problem with these methods is that they do not complement each other in the absence of an integrated analytical center where all information could be dispatched.

The new integrated center is expected to be free of the drawbacks of the existing system while complying with the principles of biosurveillance [10]. The center should not take on functions already distributed between other agencies (analysis of disease incidence, investigation of outbreaks, control of consumer goods safety, epidemiological research in subpopulations at risk). The center is expected to estimate the prevalence of biopathogens in the population, identify their types and serological markers, contributing to the task of reducing the vulnerability of the society, the economy and the state in the face of biological threats.

This center must provide functional and organizational support to emergency responder agencies in the event of a biological threat and increase their efficiency by ensuring a more rapid response. The schematic of a network for biological surveillance is shown in Fig. 2.

At the same time, interagency coordination and data pooling are not the only activities that ensure efficient performance of the national system for biosecurity and safety. The vulnerability of the society largely depends on the properties of both BPs and tools for their detection.

Human component in screening tests.

Low rate of pathogen detection

Arranging scattered sources of data into a network that continuously supplies information about current biological 
risks to the integrated center for biological surveillance can significantly reduce response time in the event of a biological threat. At the same time, the lack of information sources or the lack of specificity, sensitivity, operational independence, or automation and low rates of pathogen detection are a threat of their own. Specifically, response to an alert about a potential biohazard reported by a common lab affiliated with an HCF or a center for hygiene and epidemiology (even if it is properly equipped) can be unacceptably imprompt, considering the time required for testing procedures, data transfer, and decision making and the time a patient needs to realize that he/she is sick, present to hospital, undergo tests, etc.

Therefore, a center for biological surveillance cannot solely rely on aggregating data from third parties but needs its own network of laboratories equipped with automated tools for realtime pathogen detection [19].

Advances in laboratory diagnostics have boosted the development of techniques for rapid automated pathogen detection that require little or no human participation and can be used along with traditional manually operated tools [19]. Being highly sensitive and specific, new automated tools reduce the time of the analysis down to a few hours or even minutes. Automated devices can keep on analyzing samples collected from the environment for the presence of pathogens almost non-stop.

Analysis of airborne aerosol particles facilitates detection of pathogens in the air before the latter can be contracted by humans, which, considering the incubation period, ensures early diagnosis and drastically reduces the number of individuals who can get infected, given that adequate measures are taken urgently. The saved time can be spent on launching large-scale immunization campaigns or promoting prevention immunoglobulin therapy.

So far, immuno- and nucleic acid assays remain the most reliable techniques for automated detection of various pathogens (bacteria, viruses and toxins) in the surrounding environment [19]. Immunoassays are capable of detecting intra- and extracellular BPs and the products of their metabolism. Nucleic acid assays exhibit higher sensitivity in smaller samples [19]. The use of both techniques in combination significantly reduces the risk of false-positive results $[19,20]$, whereas their ability to quantify the analyte in the sample increases their informative value.

At the same time, requirements for operational independence and automation impose certain limitations on these devices and assays. The number of stages in the procedure must be minimized. The assays are expected to retain acceptable sensitivity (at least 1,000 pathogens per one $\mathrm{ml}$ of the aerosol concentrate) and specificity; both sample preparation and the analysis itself must be quick. Given the scope of their application and requirements for portability, aerosol samplers and analyzers must be small in dimensions, tolerate transportation without demanding additional tuning upon arrival, provide unfailing performance under rough conditions, and be airtight to exclude the possibility of cross-contamination and contamination of the working chamber. Maintenance and cleaning must be safe for the laboratory personnel.

Indeed, air quality control is a pressing concern. But the real scope of application of aerosol samplers and analyzers will largely depend on the capacities of these devices: the rate of analysis, sensitivity and specificity, the ability to quantify pathogen concentrations in the sampled air, costs of reagents, assays and the device itself $[6,21,22]$. These factors must be accounted for when deploying a network of automated tools for pathogen detection in the integrated national center for biological surveillance.

\section{Identification of previously unknown pathogens and pathogens with unknown characteristics}

The number of drug-resistant bacteria has been rapidly growing in the past few years. New infections are springing up in all corners of the world, and the risk of bioterrorism or biological warfare is still high. In this light, development and routine use

\section{Biological surveillance: current state}

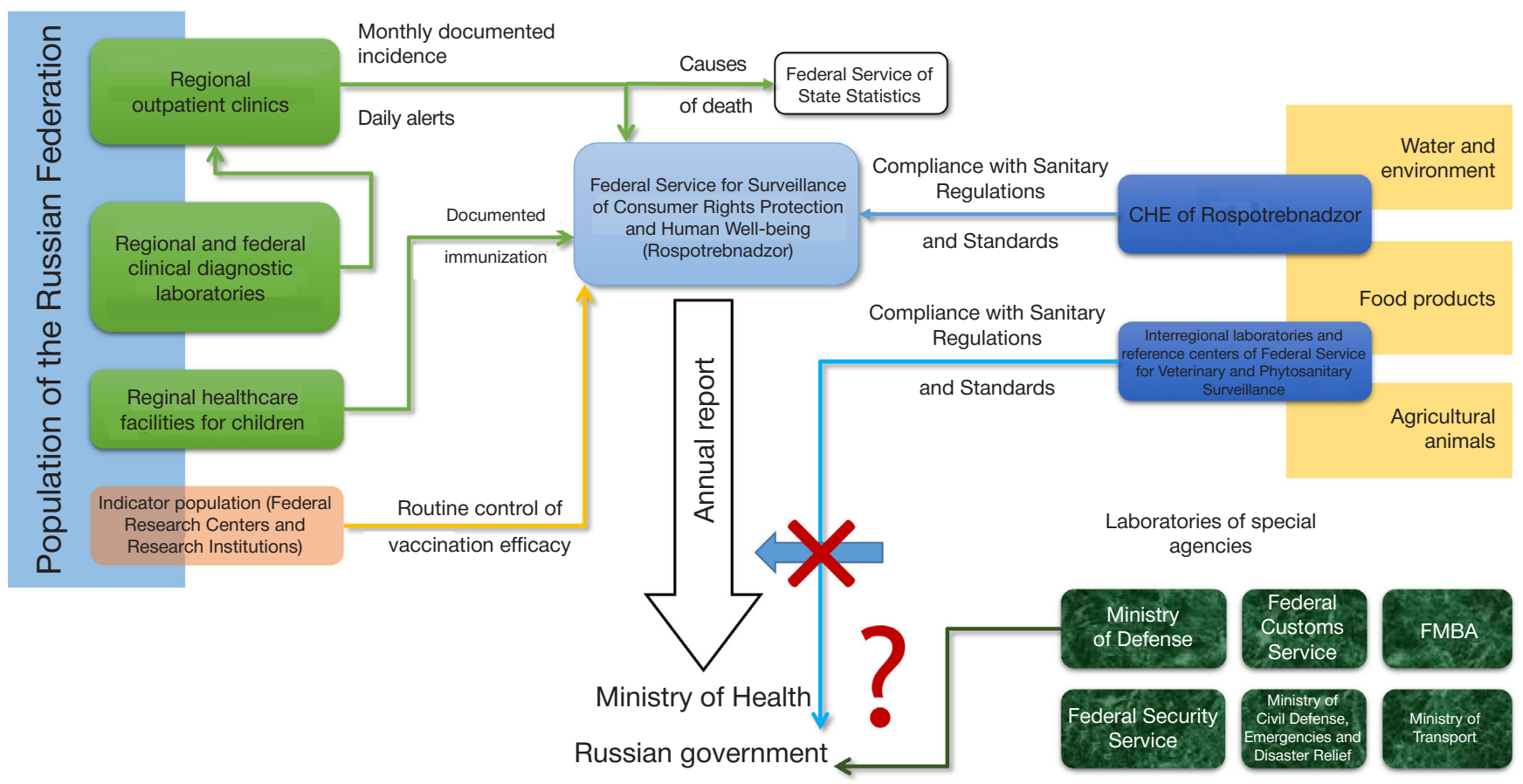

Fig. 1. The schematic representation of biological surveillance in its current state in Russia 
of novel technologies for the detection of new pathogens with unknown properties are becoming critical.

The use of high-throughput sequencing by microbiologists and infectious disease physicians has driven medical progress. Commercial tools for next-generation sequencing (NGS), including Miseq and Hiseq (Illumina), GS (Roche-454), Ion Torrent (Life Technologies), Minion (Oxford Nanopore Technologies), and PacBio (Pacific Biosciences), capable of reading the entire $\mathrm{BP}$ genomes or shorter genomic regions have made a significant contribution to clinical microbiology and virology and inspired development of new diagnostic sequencing-based techniques [23]. By deciphering genome sequences of different strains, NGS offers a unique opportunity to estimate the virulence potential of pathogen isolates and to predict their drug resistance. Identification and characterization of virulence factors, especially toxins and antibiotic resistance markers, provide an insight into the pathogenesis of bacterial diseases and bacterial interactions with the host and drive the discovery of novel drugs, vaccines and molecular diagnostic tests [10, 24].

The use of next-generation sequencing in microbiology and epidemiology opens new horizons with regard to the detection of emerging pathogens and exploration of their properties (Fig. 3).

NGS-based methods are now available in some medical microbiological laboratories, such as the laboratory at the University Medical Center Groningen (UMCG), where they are employed to control outbreaks of infectious diseases, conduct molecular epidemiology studies, create pathogen profiles, study pathogen activity, rapidly identify bacteria by their 16S-23S rRNA region, and classify microorganisms. NGS is also exploited in metagenomic approaches to clinical samples and for tracking transmission of zoonotic infections from animals to humans.

The potential of whole genome sequencing (WGS) facilitates adoption of NGS into public health research [25-26]. Applied to investigate outbreaks of infections, WGS also yields data that can be used to elaborate strategies for combatting the spread of resistant bacterial clones. For example, the outbreak caused by colistin-resistant carbapenemase-producing K. pneumonia that invaded a few Dutch hospitals was handled by referring all patients infected with this pathogen to a special healthcare facility where they received adequate treatment from a team of experts [27].

WGS has also proved to be instrumental in preparing profiles of highly virulent bacteria, such as shiga-toxin-producing Escherichia coli (STEC) O104:H4 that caused an outbreak in Germany in 2011 [28]

Molecular identification of pathogens is part of the investigation of infection outbreaks. Retrospective analysis of data yielded by NGS and WGS may reveal the involvement of pathogens that were not identified by PCR or serological techniques at the time of the outbreak [29-30].

Routine preparation of pathogen profiles is impossible without using a combination of bacteriological, biochemical and molecular techniques, rendering it labor-intensive, timeconsuming and expensive. NGS is a reliable and simple tool for exploring a variety of properties in a variety of pathogens [31-33]. Knowledge of their virulence profiles is critical for predicting the severity of the infection or treatment outcomes, as well as for risk assessment in the early stages of the disease. Because WGS covers the entire genome and not a single gene, its contribution to the detection of virulence factors may be substantial especially if assisted by special online tools [34, 35].

One of the large-scale cohort studies employed WGS to obtain a molecular profile of STEC in order to get a clear picture of the population structure and the genomic plasticity of this strain in the locations of Groningen and Rotterdam (Netherlands) [36]. Detailed information about a studied microbial strain related to its genotype, serotype, multilocus sequencing data, virulence and antibiotic resistance profiles, and phylogeny can be easily

\section{Biosurveillance: improved and enhanced}

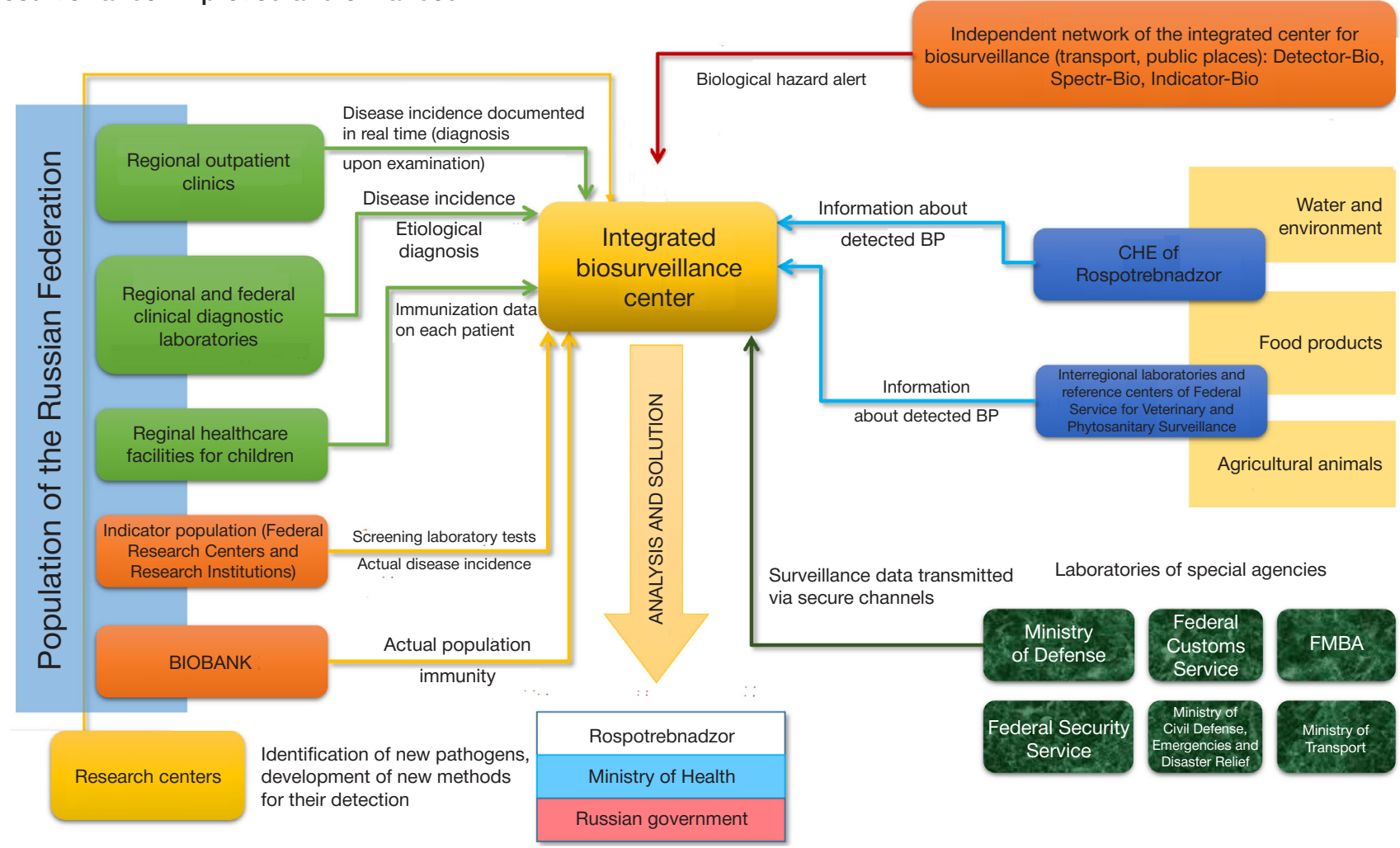

Fig. 2. Biological surveillance coordinated by the integrated national center 
extracted from special databases by running a sequence search that selectively discriminates between closely related strains. Over a short period of time, many strains have been described and compared using NGS. The important role of WGS is indisputable in situations when a need arises for efficient molecular epidemiologic surveillance in separate regions and state-wide. NGS is also good at predicting new resistance genes, including those conferring antibiotic resistance, in both modern bacteria and their ancestors; further experiments can elucidate whether these genes are really responsible for the observed patterns of antibiotic resistance [37].

NGS-based techniques do not require culturing to detect a pathogen and are capable of identifying an infinite number of pathogens, enriching our knowledge of the entire microbiome. Some authors believe that in the future metagenomics will become an ultimate approach to the detection of all possible microorganisms [38]. However, large datasets require vast bioinformatic and computational resources to be processed that are not available in the majority of diagnostic microbiological laboratories. Besides, metagenomic approaches are timeconsuming: the whole procedure takes up to 4 or 5 days.

To bridge the gap between traditional methods for the detection and identification of microorganisms (culturing, microbiological assays, PCR) and metagenomics, a cultureindependent approach has been proposed based on targeted NGS (Fig. 3). In comparison with metagenomic approaches, it is faster, cheaper and simpler and has a potential to join the routinely used arsenal of diagnostic laboratories. It has been proved that the sequence of $16 \mathrm{~S}$ rRNA gene is a reliable genetic marker of a bacterial genus (or even species or strain in some cases) as it is present in all bacteria and its function is fixed and stable [39]. This gene can be sequenced by NGS from a clinical sample without preparatory culturing. Culture-independent $16 S$ rRNA sequencing has already been adopted in clinical routine as a valuable ancillary technique $[40,41]$. However, it can produce ambiguous results as $16 \mathrm{~S}$ rRNA sequences can be similar in different bacterial species [42].

Another innovative culture-independent 16S-23S rRNA NGS-based approach has been recently developed for the detection of bacteria in clinical samples. It has a few advantages over other analytical tools. It is capable of accurate pathogen identification in urine samples, as confirmed by conventional culturing techniques [43]. Moreover, it can simultaneous identify more than one pathogen in biological samples that were previously shown to be pathogen-free by conventional culturing techniques and PCR. Indeed, this novel approach will significantly contribute to the evolution of microbiology and optimize antibiotic therapies. Finally, it will prompt clinical microbiological laboratories to routinely use NGS in their work and drive the development of technologies and bioinformatic software necessary to adapt metagenomic methods to diagnostic tasks.

In terms of taxonomy, WGS yields more gene sequences to discriminate between species than classic DNA-DNA hybridization or $16 \mathrm{~S}$ rRNA sequencing. Moreover, it can be used for phylogenetic reconstruction based on all gene sequences constituting a studied genome; conveniently, the clusters on the resulting dendrogram will be well-separated [44]. Some authors believe that profiles of new taxa should include genomic sequences with at least 20x coverage [45]

In the future NGS will help researchers to obtain more information about zoonotic transmission of BPs. Pioneer studies of this subject exploited low-selectivity techniques, such as serotyping [46]. It was not until very recently that attempts were made to use pulse-field gel electrophoresis and multiple locus variable number of tandem repeats analysis to detect specific bacterial clones in animals and humans [47]. Many aspects of biological mechanisms underlying zoonotic

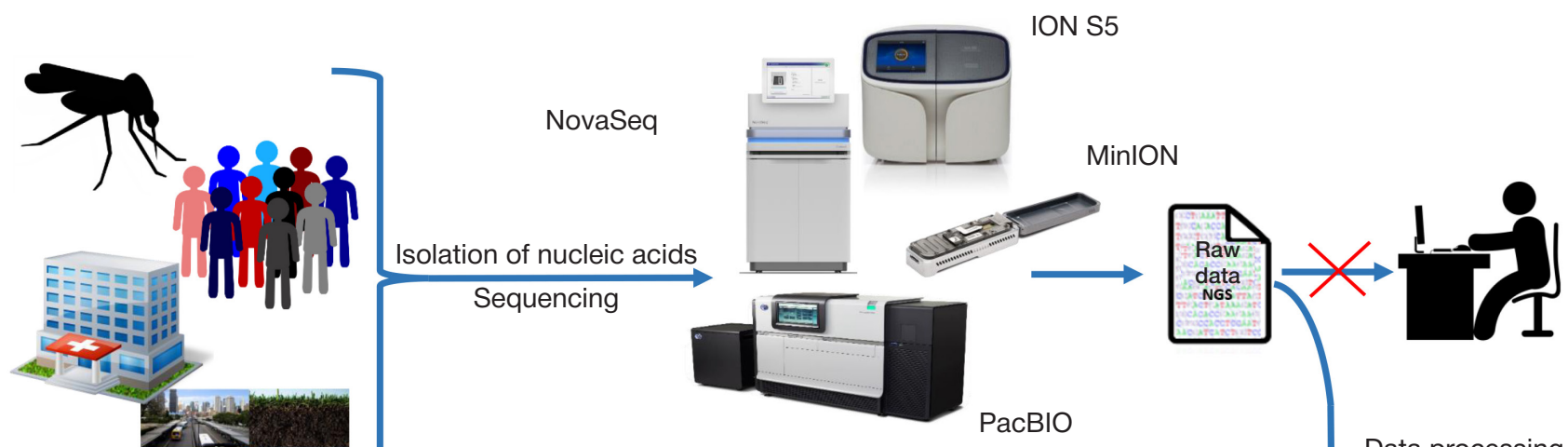

Data processing
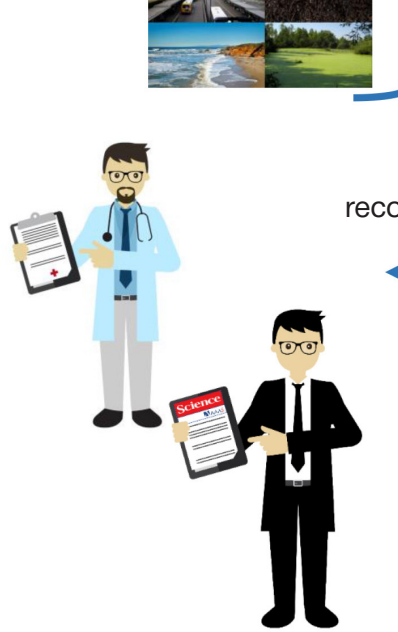

Practical recommendations
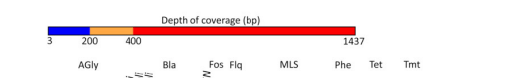

.

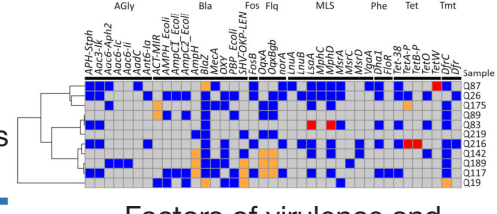

Factors of virulence and antibiotic resistance
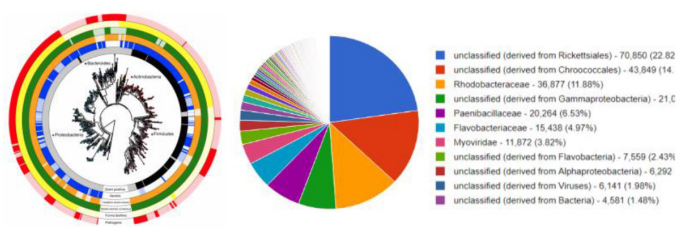

Results

Identification of bacteria and viruses and prediction of their clinical relevance

Fig. 3. Algorithm for the identification of emerging pathogens, virulence factors and antibiotic resistance of pathogenic bacteria 
transmission of infections are yet to be elucidated, including its frequency (one or more contacts with animals or animal products), associated risk factors (close contact with animals or tasks involving processing of their feces) and the contribution of antibiotics used in agriculture. Here, NGS opens new horizons. Its high selectivity allows researchers to discriminate between previously undifferentiated bacterial strains infecting animals and humans. Combined with epidemiological data, this information will help to better locate and describe the potential sources of zoonotic infections [47-48].

Together, the metagenomic approach and NGS constitute a method for creating a comprehensive profile of a pathogen covering its antibiotic resistance, the ability to produce toxins and other pathogenic factors and the ability to pass these factors on between species. However, in spite of their good potential to identify previously unknown pathogens or those with new properties, the application of NGS and metagenomic approach in clinical practice is still limited to single cases.

\section{Emergence of new biopathogens and acquisition of new pathogenic properties}

Outbreaks of infectious diseases pose a continuous threat to the population. A lot of attention is paid to the problem of emerging pathogens, such as Middle East respiratory syndrome-related coronavirus and Zaire ebolavirus. But actually, epidemics are more often caused by well-known microbes, such as influenza virus, Dengue virus, causative agents of tuberculosis, and vibrio cholerae. The majority of epidemics are a direct consequence of external influences, climate changes or geographical factors. However, they can be anthropogenic. Every few years a new threat springs up following the emergence and spread of new pathogenic organisms. The literature reports new infectious agents discovered only recently, in the 21st century [49]. A good example of the human role in the emergence of new BPs or their new properties is the spread of antibiotic-resistant strains and genetic modification of BPs intended for bioterrorism.

\section{Antibiotic resistance of human pathogens}

Resistance of pathogenic microorganisms to antimicrobial drugs (including multidrug resistance) has become a common phenomenon and is the major factor affecting treatment outcomes in infected patients almost everywhere in the world. World Health Organization (WHO) defines it as a national security threat for many countries. It is a pressing concern highlighted in many research works [50-60].

Discovered in the late 1930s, antibiotics have saved millions of people from death of acute bacterial infections. For example, the use of penicillin $\mathrm{G}$, the "magic bullet", led to a dramatic decline in streptococcus-associated mortality during World War II. By the time the first penicillin-resistant strains appeared, second-generation antibiotics had already been developed such as methicillin, cephalothin, and imipenem. However, not many years passed before a methicillin-resistant strain of Staphylococcus aureus MRSA was isolated in 1961. The following years saw the arrival of other clinical strains resistant to streptomycin, chloramphenicol and tetracycline. It soon became clear that bacteria are capable of acquiring resistance to all known antibacterial drugs. As a rule, microorganisms become resistant to an antibiotic after a year or two of its use. Many pharmaceutical companies suspended or shut down antibiotic discovery projects because the drugs were no longer profitable due to their poor efficacy. Since 1987, not a single class of antibiotics has been discovered. Today, too few drugs addressing the problem of antibiotic resistance are being designed and tested [61]. Global healthcare achievements are at risk: antibiotic resistance is spreading across the world leaving patients vulnerable in the face of deadly infections and interfering with livesaving treatments, such as surgery and chemotherapy [62-65].

Resistance to antibiotics is largely a result of their misor overuse. Statistically, in about $75 \%$ of cases prescription of antibiotics is not justifiable [64]. Monoresistant strains gradually acquire multidrug and then pandrug resistance. A new concept of "problematic" microorganisms has emerged recently referring to pathogens with multidrug and extensive drug resistance, most of which are contracted in healthcare facilities where antibiotics and disinfectants are used in abundance. Among problematic bacteria are Staphylococcus aureus, Pseudomonas aeruginosa, Klebsiella pneumoniae, enterococci, pneumococci, and some others [66].

Bacterial resistance to antibiotics is determined genetically and supported by a number of well-known mechanisms, including inactivation of the antibiotic, modification of its target, increased efflux, reduced permeability of outer membranes, and bypass of metabolic pathways [67]. It means that antibiotic-resistant strains can be directly detected by PCR or sequencing, without prior culturing in the media supplemented with antibiotics and without the need to identify a species of the studied pathogen (antibiotic resistance genes are often transferred horizontally even between different taxa). In a word, there is an available arsenal of tools for routine detection of antibiotic-resistant strains posing a serious biological threat that can be used by the integrated center for biological surveillance.

\section{Synthetic biology and bioterrorism}

Although the Geneva protocol ratified in 1925 and so far signed by 65 states prohibits development, production and use of biological and chemical weapons, it was still thought justifiable that BPs could be used in a war as their components [68]. Biological and chemical weapons sprayed in Vietnam during the Vietnam war were reported by $\mathrm{WHO}$ and condemned by the 1967 UN resolution (XXI). In 1970 WHO released a report about the Health aspects of chemical and biological weapons revised in 2004 and re-published under the heading Public health response to biological and chemical weapons [69]. This document provides guidance for preparing to outbreaks of rare exotic infections. It also includes standard recommendations for public health surveillance and adequate medical help in the event of an emergency. WHO defines biological weapons as those that destroy the target by infecting it with disease-producing agents, such as viruses, infectious nucleic acids and prions.

A variety of available technologies makes production of biological weapons a relatively easy task, and the only reason why such weapons are not developed openly is a fear of sanctions or retaliation. Many countries can potentially use biological weapons. Since 1928 some states have been planning an offensive biological warfare and most likely have the resources to initiate it now [70]. The USA (until 1972) and the former USSR (until 1992) had very elaborate doctrines of biological warfare. Both states designed over 10 biological agents, including toxins, aimed at killing or seriously wounding people and destroying agriculture on enemy territory [71, 72]. At the same time, the military use of biological agents is forbidden by the Biological and Toxin Weapons Convention (BTWC). The states that joined the Convention cannot develop, produce or stockpile biological weapons. The Convention was signed and approved by 170 states. However, there are no real mechanisms to control how well the parties to this Convention 
adhere to its terms. Development of biological weapons and its production can be easily "blended" into the biotechnological infrastructure of the state. Besides, the Convention does not demand the signees not to "develop, produce, stockpile or otherwise acquire or retain microbial or other biological agents, or toxins whatever their origin or method of production, of types and in quantities that have no justification for prophylactic, protective or other peaceful purposes". It means that the Convention does not specify what biological agents or toxins are banned and in what quantities. However, chances are that if a country takes a risk of developing or producing biological weapons regardless of whether it has joined the Convention or not, it can easily earn a reputation of a rouge state.

Bioterrorism attacks launched in non-belligerent states were first considered a local threat, and heir consequences were not thought to threaten national security. But after letters containing anthrax spores were sent through the US mail, the nightmare became a reality. The anthrax attack killed 5 and infected over 20 people. As many as a few thousands of people had to take strong antibiotics. The letters containing real or fake anthrax spores were also found in dozens of other countries, including Russia.

Bioterrorism is the deliberate dissemination of viruses, bacteria or other pathogenic agents that kill or infect people, animals and plants [73]. As a rule, terrorists seek to spark panic or fear and to cause social unrest or economic damage. Some of them are driven by ideological, religious, or political motives. Their primary tool is terror evoked by violence. Destructive doomsday cults like Aum Shinrikyo inflict mass casualties to achieve their own religious goals. However, terrorism is prosecuted by law. Counter-terrorism strategies and the lack of financial support and infrastructure obstruct implementation of successful large-scale attacks. On the other hand, for the majority of terrorists, success is probably determined by the amount of panic caused and does not need to be accompanied by a great number of casualties [74-76].

Another important phenomenon we would like to mention here is biocrime. A biocrime involves the use of a biological agent in order to kill one person or a small group of people and is largely motivated by hatred or financial gain and less by political, religious or ideological motives. For example, a situation in which ricin was used to get rid of an annoying partner or hospital staff were intentionally infected with Shigella dysenteriae by their colleague can be described as a biocrime [77]. The murder of the Bulgarian dissident writer Georgi Markov in London in 1978 by a ricin-containing pellet injected by an «umbrella gun» is another example of a biocrime.

The economic impact of bioterrorism against humans and agriculture can be truly devastating [75, 78-81].

So far bioterrorism has taken fewer lives than "traditional" attacks involving weapons and explosives. But the risk of mass casualties from infectious agents following an act of terror is real, though not so high. As a rule, the incubation period of biopathogens is long enough to detect and identify them before they start causing visible symptoms. Besides, effective antibiotic treatment is available for the majority of bacterial agents but for multidrug resistant strains.

There are two principal approaches to creating biological weapons:

a) a known pathogen is transferred from one host to another inducing severe symptoms in the latter due to the lack of adaptation of the new host;

b) a known biological agent acquires new properties, usually through horizontal gene transfer.

Before the advent of synthetic biology, creating novel biological weapons using the first approach was thought to be unlikely. Now, there is ongoing research into the mechanisms allowing prediction of mutations in the genome of a pathogen that entail the possibility of gene transfer. So, this approach is technically feasible [82-85].

Breakthroughs in synthetic biology are a fair reason to believe that in the nearest future we will witness the arrival of affordable methods for synthesizing new organisms with programmed properties that can be used in basic research and routine practice. Key discoveries in this field were made by Craig Venter, Daniel Gibson and their teams who were the first to demonstrate the possibility of synthesis of new organisms with a "designer" genome [82-85].

The potential of modern synthetic biology can be described by the following functions:

1 - combined chemical and enzymatic synthesis of long artificial DNA fragments;

2 - computer-aided design of individual genes and whole genomes with programmed metabolic functions;

3 - highly efficient assembly and editing of artificially synthesized genomes in simple biological systems (bacterial cells and single-celled eukaryotes);

4 - fully automated remote synthesis of DNA, RNA, proteins (toxins), viruses, and bacteria by robotic complexes from simple chemical compounds requiring zero human participation.

Therefore, synthetic biology can be employed to:

1) rapidly design vaccines and vaccine strains of any bacterium or virus, including known and unknown microorganisms of any nature, without using "raw" pathogenic material. The only thing one needs to have at their disposal is the genomic sequence of a pathogen that can be forwarded to a lab or an automated device as a digital message. It has been demonstrated experimentally that it takes as little as 2 months to create an influenza vaccine given that the only "raw" material available is information about the sequence of a new strain of type A flu;

2) carry out remote synthesis of bacterial cells to colonize other planets as part of space projects;

3) engineer ideal animal donors to transplant their organs to humans after introducing into their genome the loci responsible for histocompatibility;

4) design and synthesize viruses and bacteria with programmed properties that can be used in bioterrorism attacks and for military purposes.

Introduction of new pathogenic properties into known biological agents assisted by gene editing techniques and synthetic biology seems to be an easier task, as many of these organisms have already been well described. Besides, there are a lot of simple and affordable biotechnologies for horizontal gene transfer between both bacteria and viruses yielding pathogens with programmed properties. Open-access databases store information about sequences of virulence genes that can be synthesized de novo to create biological weapons even in the absence of a natural pathogen sample.

Of all currently existing approaches to pathogen engineering, genetic modification by introducing virulence genes into the genome of a pathogen is the simplest. Such modifications can include 1) incorporation of bacterial toxins into a biological target; 2) insertion of antibiotic resistance genes; 3) stimulation of excessive immune response of an infected host (cytokine storms); 4) synthesis of individual virulence genes and whole pathogenic organisms de novo.

Biological agents engineered as part of state military defense projects and pathogen repositories are another attractive target for bioterrorists. Civil wars, riots, and anarchy in the 
countries that have biological weapons increase the risk their malicious use. At the same time, innovative technologies and rapid evolution of science have improved our understanding of interactions between pathogens and their hosts and stimulated development of medical countermeasures. In addition, they have expanded our arsenal of tools for the detection and identification of pathogens. Technological novelties, such as network cameras and intelligence gathering software, have become powerful tools for combatting terrorism and enhanced the efficacy of countermeasures to prevent attacks. Advances in forensics facilitate investigation of incidents and help to track down the biological agent. However, the risk of emergence of new genetically modified pathogens is very high and poses a serious challenge to the global community.

\section{CONCLUSION}

The analysis of the available literature reporting the emergence of new pathogens deliberately synthesized by humans leads us to conclude that biological risks can be mitigated only if new techniques for rapid detection of pathogens are introduced into routine practice. Fortunately, BPs modified by humans still retain their old known properties rendering their identification technically feasible. However, unknown pathogens that spontaneously acquire dangerous properties still pose a serious threat. Therefore, the integrated center for biological surveillance must have the tools for their identification.

Biosecurity and biosafety are serious issues faced by the state. The negative impact of currently existing biological hazards, the emergence of new and the re-emergence of previously known risks threaten the sanitary, epidemiological, veterinary, phytosanitary and ecological welfare of the society and undermine the security of the state that has to be wellprepared for any type of a biological threat.

Again, risks associated with the emergence of new pathogens or the spread of those with new properties can be mitigated only if novel detection techniques are adopted into clinical routine and environmental monitoring. Particular attention should be paid to the adoption of methods for the detection of previously unknown pathogens and the development of prevention measures and adequate treatment against those re-emerged.

In this review we aimed to comprehensively analyze biological threats to national security by identifying the vulnerabilities in the current system for biological surveillance. First, these threats are a natural product of pathogen evolution through which pathogens acquire new properties enabling them to overcome immunization barriers and become antibiotic-resistant. Second, the lack of technologies for the profound analysis and rapid response to alerts is a threat of its own addressed by some of the articles in the current issue of the journal. Third, the system for biological surveillance is vulnerable in its current state due to the lack of interagency coordination and slow response to alerts. All these factors urge creation of a national integrated center for biological surveillance to promptly aggregate, process and analyze information from different sources about all possible biological threats. The collected data can be used to model how the situation will unfold, predict its outcomes, keep the officials in charge informed, and facilitate decision making at the interagency level.

\section{References}

1. O biologicheskoj bezopasnosti. Proekt Federal'nogo zakona Rossijskoj Federacii. (red. ot avgusta 2016 g.). 30 s. Dostupno po ssylke: http://regulation.gov.ru/projects\#npa=55658

2. Onishhenko GG, Popova AJu, Toporkov VP, Smolenskii VJu, Shherbakova SA, Kutyrev VV. Sovremennye ugrozy i vyzovy $\checkmark$ oblasti biologicheskoj bezopasnosti i strategija protivodejstvija. Problemy osobo opasnyh infekcij. 2015; (3): 5-9.

3. O sostojanii sanitarno-jepidemiologicheskogo blagopoluchija naselenija v Rossijskoj Federacii v 2017 godu: Gosudarstvenny doklad. M.: Federal'naja sluzhba po nadzoru v sfere zashhity prav potrebitelej i blagopoluchija cheloveka; 2018. 268 s.

4. Pokrovskij VI, Briko NI. Jepidemiologija. Uchebnik. M.: GJeOTAR-Media; 2016. 368 s.

5. Lobzin JuV, Belozerov ES, Beljaeva TV, Volzhanin VM. Virusnye bolezni cheloveka. SPb.: SpecLit; 2015. 400 s.

6. Biowatch and public health surveillance: Evaluating systems for the early detection of biological threats. Abbreviated version. Washington, DC: The National Academies Press. IOM and NRC. 2011. 252 p.

7. Onishhenko GG, Merkulov IV, Petrov EJu, Zhelobov VE, Shevchuk NA, Seledcova OV. O hode immunizacii naselenija $\checkmark$ ramkah nacional'nogo kalendarja profilakticheskih privivok. Protokol selektornogo soveshhanija u rukovoditelja Federal'noj sluzhby po nadzoru $v$ sfere zashhity prav potrebitelej i blagopoluchija cheloveka (Protokol \#13 ot 20.07.2010). Dostupno po ssylke: http://41.rospotrebnadzor. ru/content/protokol-protokol-selektornogo-soveshchaniya-urukovoditelya-federalnoy-sluzhby-po-nadzoru-5

8. Osnovy gosudarstvennoj politiki $\vee$ oblasti obespechenija himicheskoj i biologicheskoj bezopasnosti Rossijskoj

Federacii na period do 2025 goda i dal'nejshuju perspektivu (utv. Prezidentom RF 1 nojabrja 2013 g. N Pr-2573). Dostupno po ssylke: http://www.garant.ru/products/ipo/ prime/doc/70423098/

9. Ukaz Prezidenta RF ot 31.12.2015 N 683 «O Strategii nacional'noj bezopasnosti Rossijskoj Federacii». Dostupno po ssylke: http://www.consultant.ru/document/cons_doc_ LAW_191669/

10. V Rossii sozdadut Centr po bor'be s biologicheskimi ugrozami. [Jelektronnyj resurs] Paper 16 matra 2015. Dostupno po ssylke: https://iz.ru/news/584008 (last accessed 12 September 2018).

11. Postanovlenie Pravitel'stva RF ot 30 ijunja 2004 g. N 322 «Ob utverzhdenii Polozhenija o Federal'noj sluzhbe po nadzoru v sfere zashhity prav potrebitelej i blagopoluchija cheloveka» (v red. ot 24 janvarja 2017 g.). Dostupno po ssylke: http://base. garant.ru/12136005/

12. Prikaz Federal'noj sluzhby gosudarstvennoj statistiki ot 28 janvarja 2014 g. N 52 «Ob utverzhdenii statisticheskogo instrumentarija dlja organizacii Federal'noj sluzhboj po nadzoru $v$ sfere zashhity prav potrebitelej i blagopoluchija cheloveka federal'nogo statisticheskogo nabljudenija za zabolevaemost'ju naselenija infekcionnymi i parazitarnymi boleznjami i profilakticheskimi privivkami». Dostupno po ssylke: http://www.garant.ru/products/ipo/prime/doc/70479106/

13. Statisticheskij uchet i otchetnost' uchrezhdenij zdravoohranenija. M.: Ministerstvo zdravoohranenija i social'nogo razvitija Rossijskoj Federacii. 2006. $81 \mathrm{~s}$.

14. Federal'nyj zakon ot 30.03.1999 N 52-FZ «O sanitarnojepidemiologicheskom blagopoluchii naselenija» ( $v$ red. ot 03.07.2016). Dostupno po ssylke: http://www.consultant.ru/ document/cons_doc_LAW_22481/ 
15. 15. Postanovlenie Pravitel'stva RF ot 2 fevralja $2006 \mathrm{~g}$. N 60 «Ob utverzhdenii Polozhenija o provedenii social'nogigienicheskogo monitoringa» (v red. ot 4 sentjabrja 2012 g.). Dostupno po ssylke: http://base.garant.ru/12144791/

16. SanPiN 2.3.2.1078-01. Gigienicheskie trebovanija bezopasnosti i pishhevoj cennosti pishhevyh produktov. Utverzhdeny glavnym gosudarstvennym sanitarnym vrachom Rossijskoj Federacii 06 nojabrja $2001 \mathrm{~g}$. Dostupno po ssylke: http://base.garant.ru/4178234/

17. SanPiN 2.1.4.1074-01: Pit'evaja voda. Gigienicheskie trebovanija $k$ kachestvu vody centralizovannyh sistem pit'evogo vodosnabzhenija. Kontrol' kachestva. Gigienicheskie trebovanija k obespecheniju bezopasnosti sistem gorjachego vodosnabzhenija. Utverzhdeny glavnym gosudarstvennym sanitarnym vrachom Rossijskoj Federacii 29 sentjabrja $2001 \mathrm{~g}$. Dostupno po ssylke: http://docs.cntd.ru/document/901798042

18. Perechen' standartov, soderzhashhih pravila i metody ispytanij i izmerenij, v tom chisle pravila otbora obrazcov, neobhodimye dlja primenenija i ispolnenija trebovanij tehnicheskogo reglamenta Tamozhennogo sojuza «Trebovanija bezopasnosti pishhevyh dobavok, aromatizatorov i tehnologicheskih vspomogatel'nyh sredstv» i osushhestvlenija ocenki (podtverzhdenija) sootvetstvija. Prilozhenie k Edinym sanitarnojepidemiologicheskim i gigienicheskim trebovanijam $\mathrm{k}$ tovaram, podlezhashhim sanitarno-jepidemiologicheskomu nadzoru (kontrolju). Utverzhdeny Resheniem Komissii Tamozhennogo sojuza ot 28 maja 2010 goda \# 299. (v red. ot 09 dekabrja 2011 g.)

19. Dzenitis JM, Makarewicz AJ. The Autonomous Pathogen Detection System. The Microflow Cytometer. 2010: 263-84.

20. Hindson BJ, Makarewicz AJ, Setlur US, Henderer BD, McBride MT, Dzenitis JM. APDS: the autonomous pathogen detection system. Biosens Bioelectron. 2005; 20 (10): 1925-31.

21. Onishhenko GG, Kuzkin BP, Demina JuV. i dr. Obespechenie gotovnosti i organizacija raboty SPJeB FKUZ «Stavropol'skij protivochumnyj institut» Rospotrebnadzora v period provedenija XXII Olimpijskih i XI Paralimpijskih zimnih igr v Sochi. Problemy osobo opasnyh infekcii. 2015; (1): 58-62.

22. GAO-14-267T BIOSURVEILLANCE: Observations on the Cancellation of BioWatch Gen-3 and Future Considerations for the Program. GAO. Statement of Chris Currie, Acting Director, Homeland Security and Justice. Washington, D.C.: 2014

23. Fournier PE, Raoult D. Prospects for the future using genomics and proteomics in clinical microbiology. Annu Rev Microbiol. 2011; (65): 169-188.

24. Diene SM, Bertelli C, Pillonel T, Schrenzel J, Greub G. Bacterial genomics and metagenomics: clinical applications and medical relevance. Rev Med Suisse. 2014; 10 (450): 2155-61.

25. Zhou K, Ferdous M, de Boer RF, Kooistra-Smid AM, Grundmann H, Friedrich AW, et al. The mosaic genome structure and phylogeny ofShiga toxin-producing Escherichia coli O104:H4 is driven by short-termadaptation. Clin Microbiol Infect. 2015; 21 (468): e467-18.

26. Zhou K, Lokate M, Deurenberg RH, Tepper M, Arends JP, Raangs $E G$, et al. Use ofwhole-genome sequencing to trace, control and characterize the regionalexpansion of extended-spectrum beta-lactamase producing ST15 Klebsiellapneumoniae. Sci Rep. 2016; (6): 20840.

27. Weterings V, Zhou K, Rossen JW, van Stenis D, Thewessen E, Kluytmans J, et al. An outbreak of colistin-resistant Klebsiella pneumoniaecarbapenemase-producing Klebsiella pneumoniae in the Netherlands (July-December 2013), with inter-institutional spread. Eur J Clin Microbiol Infect Dis. 2015; (34): 1647-55

28. Ferdous M, Zhou K, de Boer RF, Friedrich AW, KooistraSmid AM, Rossen JW, Comprehensive characterization of Escherichia coli 0104:H4isolated from patients in the Netherlands. Front Microbiol. 2015; (6): 1348.

29. Bathoorn E, Rossen JW, Lokate M, Friedrich AW, Hammerum AM. Isolation of an NDM-5-producing ST16 Klebsiella pneumoniae from a Dutchpatient without travel history abroad, August 2015. Euro Surveil. 2015; (20): 30040.

30. Falgenhauer L, Waezsada SE, Yao Y, Imirzalioglu C, Kasbohrer A,
Chakraborty T. Colistin resistance gene mcr-1 in extendedspectrumbeta-lactamase-producing and carbapenemaseproducing Gram-negativebacteria in Germany. Lancet Infect Dis. 2016; (16): 282-283.

31. Aanensen DM, Feil EJ, Holden MT, Dordel J, Yeats CA, Fedosejev $A$, et al. Whole-genome sequencing for routine pathogen surveillancein public health: a population snapshot of invasive Staphylococcus aureus in Europe. Mbio. 2016; 7 (3): e00444-16.

32. Fournier PE, Dubourg G, Raoult D. Clinical detection and characterizationof bacterial pathogens in the genomics era. Genome Med. 2014; (6): 114.

33. Hasman H, Saputra D, Sicheritz-Ponten T, Lund O, Svendsen CA, Frimodt-Moller $N$, et al. Rapid whole-genome sequencing fordetection and characterization of microorganisms directly from clinicalsamples. J Clin Microbiol. 2014; (52): 139-46.

34. Franz E, Delaquis P, Morabito S, Beutin L, Gobius K, Rasko DA, et al. Exploiting the explosion ofinformation associated with whole genome sequencing to tackle Shigatoxin-producing Escherichia coli (STEC) in global food production systems. Int J Food Microbiol. 2014; (187): 57-72.

35. Laabei M, Recker M, Rudkin JK, Aldeljawi M, Gulay Z, Sloan TJ, et al. Predicting the virulence of MRSA from its genome sequence. Genome Res. 2014; (24): 839-49.

36. Ferdous M, Friedrich AW, Grundmann H, de Boer RF, Croughs PD, Islam MA, et al. Molecular characterization and phylogeny of Shiga toxin-producingEscherichia coli isolates obtained from two Dutch regions using whole genomesequencing. Clin Microbiol Infect 2016; (22): 642.e1-642.e9.

37. Nijhuis RH, Oueslati S, Zhou K, Bosboom RW, Rossen JW, Naas $T$, et al. OXY-2-15, a novel variant showing increased ceftazidime hydrolytic activity. J Antimicrob Chemother. 2015; (70): 1429-33.

38. Hasman H, Saputra D, Sicheritz-Ponten T, Lund O, Svendsen CA, Frimodt-Moller N, et al. Rapid whole-genome sequencing fordetection and characterization of microorganisms directly from clinicalsamples. J Clin Microbiol 2014; (52): 139-46.

39. Patel JB. 16S rRNA gene sequencing for bacterial pathogen identification inthe clinical laboratory. Mol Diagn. 2001; (6): 313-21.

40. Schuurman T, de Boer RF, Kooistra-Smid AM, van Zwet AA Prospectivestudy of use of PCR amplification and sequencing of $16 \mathrm{~S}$ ribosomal DNA fromcerebrospinal fluid for diagnosis of bacterial meningitis in a clinical setting. J Clin Microbiol. 2004; (42): 734-40.

41. Srinivasan L, Pisapia JM, Shah SS, Halpern CH, Harris MC. Canbroad-range $16 \mathrm{~S}$ ribosomal ribonucleic acid gene polymerase chain reactionsimprove the diagnosis of bacterial meningitis? A systematic review andmeta-analysis. Ann Emerg Med. 2012; (60): 609-20.

42. Kalia VC, Kumar R, Kumar P, Koul S. A genome-wide profiling strategy asan aid for searching unique identification biomarkers for Streptococcus. Indian J Microbiol. 2016; (56): 46-58.

43. Sabat AJ, van Zanten E, Akkerboom V, Wisselink G, van Slochteren K, de Boer RF. Targetedamplification for bacterial identification at the species-level usingnextgeneration sequencing-increased discrimination of closely relatedspecies. ECCMID. 2016; E-poster EP0219.

44. Daubin V, Gouy M, Perriere G. Bacterial molecular phylogeny usingsupertree approach. Genome Inform. 2001; (12): 155-64.

45. Thompson CC, Chimetto L, Edwards RA, Swings J, Stackebrandt E, Thompson FL. Microbial genomic taxonomy. BMC Genom. 2013; (14): 913.

46. Tenover FC, Arbeit RD, Goering RV. How to select and interpretmolecular strain typing methods for epidemiological studies of bacterialinfections: a review for healthcare epidemiologists. Molecular Typing WorkingGroup of the Society for Healthcare Epidemiology of America. Infect Control Hosp Epidemiol. 1997; (18): 426-39.

47. Sabat AJ, Budimir A, Nashev D, Sa-Leao R, van Dijl J, Laurent $F$, et al. Overview of molecular typing methods for outbreakdetection and epidemiological surveillance. Euro Surveil. 2013; (18): 20380 
48. Harrison EM, Paterson GK, Holden MT, Larsen J, Stegger M Larsen AR, et al. Whole genomesequencing identifies zoonotic transmission of MRSA isolates with the novelmecA homologue mecC. EMBO Mol Med. 2013; (5): 509-15.

49. Makarov V, Hromov AV, Gushhin VA, Tkachuk AP. Vozniknovenie novyh infekcij v 21 veke i sposoby ih identifikacil $\mathrm{s}$ ispol'zovaniem vysokoproizvoditel'nogo sekvenirovanija (NGS). Vestnik RGMU. 2017; (1): 5-25.

50. Jakovlev SV, Suvorova MP, Beloborodov VB, Basin EE, Eliseeva EV, Kovelenov SV. i dr. Rasprostranennost' i klinicheskoe znachenie nozokomial'nyh infekcij v lechebnyh uchrezhdenijah Rossii: issledovanie JeRGINI. Antibiotiki i himioterapija 2016; 61 (5-6): 32-42.

51. Kozlov RS. Pnevmokokki: uroki proshlogo - vzgljad v budushhee. Smolensk: MAKMAH; 2010.

52. Paterson DL, Rossi F, Baquero F, et al. In vitro susceptibilities of aerobic and facultative Gram-negative bacilli isolated from patient with intra-abdominal infections worldwide: the 2003 Study for Monitoring Antimicrobial Resistance Trend (SMART). J Antimicrob Chemother. 2005; (55): 965-73.

53. Nauchnyj otchet o rezul'tatah issledovanija antibiotikorezistentnosti bakterial'nyh vozbuditelej nozokomial'nyh infekcij $v$ otdelenijah $s$ intensivnym ispol'zovaniem antibiotikov v stacionarah Rossii (ReVANSh). Smolensk: Nauchno-issledovatel'skij institut antimikrobno himioterapii; 2009.

54. Bonomo RA, Burd EM, Conly J, Limbago BM, Poirel L, Segre JA, Westblade LF. Carbapenemase-Producing Organisms: A Global Scourge. Clin Infect Dis. 2017 Oct 16

55. Kohler PP, Volling C, Green K, Uleryk EM, Shah PS, McGeer A. Carbapenem Resistance, Initial Antibiotic Therapy, and Mortality in Klebsiella pneumoniae Bacteremia: A Systematic Review and Meta-Analysis. Infect Control Hosp Epidemiol. 2017 Nov; 38 (11): 1319-28.

56. Zavascki AP, Barth AL, Gaspareto PB, et al. Risk factors for nosocomial infections due to Pseudomonas aeruginosa producing metallo-beta-lactamase in two tertiary-care teaching hospitals. J Antimicrob Chemother. 2006; (58): 882-5.

57. Messadi AA, Lamia T, Kamel B, et al. Association between antibiotic use and changes in susceptibility patterns of $P$. aeruginosa in an intensive care unit: a 5-year study, 20002004. Burns. 2008; (34):1098-102.

58. Jakovlev SV, Procenko DN, Shahova TV. i $d r$. Antibiotikorezistentnost' $v$ stacionare: kontroliruem li my situaciju? Antibiotiki i himioterapija. 2010; 55 (1-2): 50-58.

59. Tacconelli E, De Angelis G, Cataldo MA, et al. Does antibiotic exposure increase the risk of methicillinresistant Staphylococcus aureus (MRSA) isolation? A systematic review and meta-analysis. J Antimicrob Chemother. 2008; (61): 2638.

60. Sarma JB, Ahmed GU. Characterisation of methicillin resistant S. aureus strains and risk factors for acquisition in a teaching hospital in northeast India. Indian J Med Microbiol. 2010; (28): 127-9.

61. Fair RJ, Tor Y. Antibiotics and bacterial resistance in the 21st century. Perspect Med Chem. 2014; (6): 25-64.

62. Curcio D. Multidrug-resistant Gram-negative bacterial infections: are you ready for the challenge? Curr Clin Pharmacol. 2014; (9): 27-38.

63. De Angelis GD, D'Inzeo T, Fiori B, et al. Burden of antibiotic resistant Gram-negative bacterial infections: evidence and limits. J Med Microbiol Diagn. 2014; (3): 132-37.

64. Global'nyj plan dejstvij po bor'be s ustojchivost'ju k protivomikrobnym preparatam. VOZ. 2016 g. 7 s. Dostupno po ssylke: http://apps.who.int/gb/ebwha/pdf_files/WHA69/ A69_24-ru.pdf

65. Jakovlev SV, Procenko DN, Shahova TV. i dr. Antibiotikorezistentnost' $v$ stacionare: kontroliruem li my situaciju? Antibiotiki i himioterapija. 2010; 55 (1-2): 50-8.
66. Jakovlev SV, Sidorenko SV, Rafal'skij VV, Spichak TV, redaktory. Strategija i taktika racional'nogo primenenija antimikrobnyh sredstv $v$ ambulatornoj praktike. Rossijskie prakticheskie rekomendacii. M.: Izdatel'stvo «Pre100print»; 2014. $121 \mathrm{~s}$

67. Blair JM, Webber MA, Baylay AJ, et al. Molecular mechanisms of antibiotic resistance. Nat Rev Microbiol. 2015; (13): 42-51.

68. The Protocol for the Prohibition of the Use in War of Asphyxiating, Poisonous or Other Gases, and of Bacteriological Methods of Warfare. United Nations (1925). Available from: http://www. un.org/disarmament/WMD/Bio/1925GenevaProtocol.shtml (last accessed 12 December 2015).

69. World Health Organization. Public health response to biological and chemical weapons - WHO guidance, 2nd edn. Geneva: WHO, 2004

70. Nuclear Threat Initiative. Available from: http://www.nti.org/ country-profiles (last accessed 12 December 2015).

71. Atlas RM. The medical threat of biological weapons. Crit Rev Microbiol. 1998; (24): 157-68.

72. Leitenberg M, Zilinskas RA, editors. The Soviet biological weapons program: a history. Cambridge, MA: Harvard University Press; 2012.

73. Centers for Disease Control and Prevention. Webpage Emergency Preparedness and Response. Specific hazards: Bioterrorism. Available from: http://www.bt.cdc.gov/ bioterrorism (last accessed 12 December 2015).

74. Carus WS. Bioterrorism and biocrimes: the illicit use of biological agents since 1900. February 2001 revision. Washington, DC: Center for Counterproliferation Research, National Defense University. 2001. Available from: http://www.fas.org/irp/ threat/cbw/carus.pdf (last accessed 12 December 2015).

75. Ackermann GA, Moran KS. Bioterrorism and threat assessment. Weapons of Mass Destruction Commission. 2004. Available from: www.blixassociates.com/wp-content/ uploads/2011/03/No22.pdf (last accessed 12 December 2015).

76. Dando M. Bioterrorism: what is the real threat? Science and Technology Report No. 3. UK Global Health Policy Programme. London: The Nuffield Trust, 2005

77. Kolavic SA, Kimura A, Simons SL, et al. An outbreak of Shigella dysenteriae Type 2 among laboratory workers due to intentional food contamination. JAMA. 1997; (278): 396-8.

78. Wheelis M, Casagrande R, Madden LV. Biological attack on agriculture: low-tech, high-impact bioterrorism. Bioscience. 2002; (52): 569-76.

79. Bourn J. The 2001 Outbreak of Foot and Mouth Disease. Report by the Comptroller and Auditor General, HC 939 Session 2001-2002. London, UK, National Audit Office. 2002. Available from: www.nao.gov.uk (last accessed 12 December 2015).

80. Meuwissen MPM, Van Boven M, Hagenaars TJ, et al. Predicting future costs of high-pathogenicity avian influenza epidemics: large versus small uncertainties. NJAS. 2006; (52): 195-205.

81. Schmitt K, Zacchia NA. Total decontamination cost of the anthrax letter attacks. Biosecur Bioterror. 2012; (10): 1-10.

82. Gibson DG1, Glass JI, Lartigue C, Noskov VN, Chuang RY, Algire MA, et al. Creation of a bacterial cell controlled by a chemically synthesized genome. Science. 2010 Jul 2; 329 (5987): 52-6. DOI: 10.1126/science.1190719.

83. Gibson DG, Venter JC. Synthetic biology: Construction of a yeast chromosome. Nature. 2014 May 8; 509 (7499): 168-9. DOI: $10.1038 / 509168$.

84. Hutchison CA, Chuang RY, Noskov VN, Assad-Garcia N, Deerinck TJ, Ellisman $\mathrm{MH}$, et al. Design and synthesis of a minimal bacterial genome. Science. 2016 Mar 25; 351 (6280): aad6253. DOI: 10.1126/science.aad6253.

85. Boles KS, Kannan K, Gill J, Felderman M, Gouvis H, Hubby B, et al. Digital-to-biological converter for on-demand production of biologics. Nature Biotechnology. 2017; (35): 672-5 
1. О биологической безопасности. Проект Федерального закона Российской Федерации. (ред. от августа 2016 г.). 30 с. Доступно по ссылке: http://regulation.gov.ru/projects\# npa $=55658$

2. Онищенко Г. Г., Попова А. Ю., Топорков В. П., Смоленский В. Ю., Щербакова С. А., Кутырев В. В. Современные угрозы и вызовы в области биологической безопасности и стратегия противодействия. Проблемы особо опасных инфекций. 2015; (3): 5-9.

3. О состоянии санитарно-эпидемиологического благополучия населения в Российской Федерации в 2017 году: Государственный доклад. М.: Федеральная служба по надзору в сфере защиты прав потребителей и благополучия человека; 2018. 268 с.

4. Покровский В .И., Брико Н. И. Эпидемиология. Учебник. М.: ГЭОТАР-Медиа; 2016. 368 с.

5. Лобзин Ю. В., Белозеров Е. С., Беляева Т. В, Волжанин В. М. Вирусные болезни человека. СПб.: СпецЛит; 2015. $400 \mathrm{c}$.

6. BioWatch and public health surveillance: Evaluating systems for the early detection of biological threats. Abbreviated version. Washington, DC: The National Academies Press. IOM and NRC. 2011. 252 p.

7. Онищенко Г. Г., Меркулов И. В., Петров Е. Ю., Желобов В. Е., Шевчук Н. А., Селедцова О. В. О ходе иммунизации населения В рамках национального календаря просилактических прививок. Протокол селекторного совещания у руководителя Федеральной службы по надзору в сфере защиты прав потребителей и благополучия человека (Протокол №13 от 20.07.2010). Доступно по ссылке: http://41.rospotrebnadzor.ru/content/protokol-protokolselektornogo-soveshchaniya-u-rukovoditelya-federalnoysluzhby-po-nadzoru-5

8. Основы государственной политики в области обеспечения химической и биологической безопасности Российской Федерации на период до 2025 года и дальнейшую перспективу (утв. Президентом РФ 1 ноября 2013 г. N Пр2573). Доступно по ссылке: http://www.garant.ru/products/ ipo/prime/doc/70423098/

9. Указ Президента РФ от 31.12.2015 N 683 «О Стратегии национальной безопасности Российской Федерации". Доступно по ссылке: http://www.consultant.ru/document/ cons_doc_LAW_191669/

10. В России создадут Центр по борьбе с биологическими угрозами. [Электронный ресурс] Paper 16 матра 2015. Доступно по ссылке: https://iz.ru/news/584008 (last accessed 12 September 2018).

11. Постановление Правительства РФ от 30 июня 2004 г. N 322 «Об утверждении Положения о Федеральной службе по надзору в сфере защиты прав потребителей и благополучия человека» (в ред. от 24 января 2017 г.). Доступно по ссылке: http://base.garant.ru/12136005/

12. Приказ Федеральной службы государственной статистики от 28 января 2014 г. N 52 «Об утверждении статистического инструментария для организации Федеральной службой по надзору в сфере защиты прав потребителей и благополучия человека федерального статистического наблюдения за заболеваемостью населения инфекционными и паразитарными болезнями и профилактическими прививками». Доступно по ссылке: http://www.garant.ru/products/ipo/prime/doc/70479106/

13. Статистический учет и отчетность учреждений здравоохранения. М.: Министерство здравоохранения и социального развития Российской Федерации. 2006. 81 с.

14. Федеральный закон от 30.03.1999 N 52-Ф3 «О санитарноэпидемиологическом благополучии населения» (в ред. от 03.07.2016). Доступно по ссылке: http://www.consultant.ru/ document/cons_doc_LAW_22481/

15. Постановление Правительства РФ от 2 февраля 2006 г. N 60 «Об утверждении Положения о проведении социальногигиенического мониторинга» (в ред. от 4 сентября 2012 г.).
Доступно по ссылке: http://base.garant.ru/12144791/

16. СанПин 2.3.2.1078-01. Гигиенические требования безопасности и пищевой ценности пищевых продуктов. Утверждены главным государственным санитарным врачом Российской Федерации 06 ноября 2001 г. Доступно по ссылке: http://base.garant.ru/4178234/

17. СанПиН 2.1.4.1074-01: Питьевая вода. Гигиенические требования к качеству воды централизованных систем питьевого водоснабжения. Контроль качества. Гигиенические требования к обеспечению безопасности систем горячего водоснабжения. Утверждены главным государственным санитарным врачом Российской Федерации 29 сентября 2001 г. Доступно по ссылке: http:// docs.cntd.ru/document/901798042

18. Перечень стандартов, содержащих правила и методы испытаний и измерений, в том числе правила отбора образцов, необходимые для применения и исполнения требований технического регламента Таможенного союза «Требования безопасности пищевых добавок, ароматизаторов и технологических вспомогательных средств» и осуществления оценки (подтверждения) соответствия. Приложение к Единым санитарноэпидемиологическим и гигиеническим требованиям к товарам, подлежащим санитарно-эпидемиологическому надзору (контролю). Утверждены Решением Комиссии Таможенного союза от 28 мая 2010 года № 299. (в ред. от 09 декабря 2011 г.)

19. Dzenitis JM, Makarewicz AJ. The Autonomous Pathogen Detection System. The Microflow Cytometer. 2010: 263-84.

20. Hindson BJ, Makarewicz AJ, Setlur US, Henderer BD, McBride MT, Dzenitis JM. APDS: the autonomous pathogen detection system. Biosens Bioelectron. 2005; 20 (10): 1925-31.

21. Онищенко Г. Г., Кузькин Б. П., Демина Ю. В. и др. Обеспечение готовности и организация работы СПЭБ ФКУЗ «Ставропольский противочумный институт» Роспотребнадзора в период проведения XXII Олимпийских и XI Паралимпийских зимних игр в Сочи. Проблемы особо опасных инфекций. 2015; (1): 58-62.

22. GAO-14-267T BIOSURVEILLANCE: Observations on the Cancellation of BioWatch Gen-3 and Future Considerations for the Program. GAO. Statement of Chris Currie, Acting Director, Homeland Security and Justice. Washington, D.C.: 2014

23. Fournier PE, Raoult D. Prospects for the future using genomics and proteomics in clinical microbiology. Annu Rev Microbiol. 2011; (65): 169-188.

24. Diene SM, Bertelli C, Pillonel T, Schrenzel J, Greub G. Bacterial genomics and metagenomics: clinical applications and medical relevance. Rev Med Suisse. 2014; 10 (450): 2155-61.

25. Zhou K, Ferdous M, de Boer RF, Kooistra-Smid AM, Grundmann $\mathrm{H}$, Friedrich AW, et al. The mosaic genome structure and phylogeny ofShiga toxin-producing Escherichia coli O104: $\mathrm{H} 4$ is driven by short-termadaptation. Clin Microbiol Infect. 2015; 21 (468): e467-18

26. Zhou K, Lokate $M$, Deurenberg $\mathrm{RH}$, Tepper $\mathrm{M}$, Arends JP, Raangs EG, et al. Use ofwhole-genome sequencing to trace, control and characterize the regionalexpansion of extended-spectrum beta-lactamase producing ST15 Klebsiellapneumoniae. Sci Rep. 2016; (6): 20840.

27. Weterings V, Zhou K, Rossen JW, van Stenis D, Thewessen E, Kluytmans $\mathrm{J}$, et al. An outbreak of colistin-resistant Klebsiella pneumoniaecarbapenemase-producing Klebsiella pneumoniae in the Netherlands (July-December 2013), with interinstitutional spread. Eur J Clin Microbiol Infect Dis. 2015; (34): 1647-55.

28. Ferdous M, Zhou K, de Boer RF, Friedrich AW, KooistraSmid AM, Rossen JW, Comprehensive characterization of Escherichia coli O104:H4isolated from patients in the Netherlands. Front Microbiol. 2015; (6): 1348.

29. Bathoorn E, Rossen JW, Lokate M, Friedrich AW, Hammerum AM Isolation of an NDM-5-producing ST16 Klebsiella pneumoniae from a Dutchpatient without travel history abroad, August 
2015. Euro Surveil. 2015; (20): 30040.

30. Falgenhauer L, Waezsada SE, Yao Y, Imirzalioglu C, Kasbohrer A, Chakraborty T. Colistin resistance gene mcr-1 in extendedspectrumbeta-lactamase-producing and carbapenemaseproducing Gram-negativebacteria in Germany. Lancet Infect Dis. 2016; (16): 282-283.

31. Aanensen DM, Feil EJ, Holden MT, Dordel J, Yeats CA, Fedosejev $A$, et al. Whole-genome sequencing for routine pathogen surveillancein public health: a population snapshot of invasive Staphylococcus aureus in Europe. Mbio. 2016; 7 (3): e00444-16.

32. Fournier PE, Dubourg G, Raoult D. Clinical detection and characterizationof bacterial pathogens in the genomics era. Genome Med. 2014; (6): 114

33. Hasman H, Saputra D, Sicheritz-Ponten T, Lund O, Svendsen CA Frimodt-Moller $\mathrm{N}$, et al. Rapid whole-genome sequencing fordetection and characterization of microorganisms directly from clinicalsamples. J Clin Microbiol. 2014; (52): 139-46.

34. Franz E, Delaquis P, Morabito S, Beutin L, Gobius K, Rasko DA et al. Exploiting the explosion ofinformation associated with whole genome sequencing to tackle Shigatoxin-producing Escherichia coli (STEC) in global food production systems. Int J Food Microbiol. 2014; (187): 57-72.

35. Laabei M, Recker M, Rudkin JK, Aldeljawi M, Gulay Z, Sloan TJ, et al Predicting the virulence of MRSA from its genome sequence. Genome Res. 2014; (24): 839-49.

36. Ferdous M, Friedrich AW, Grundmann H, de Boer RF, Croughs PD, Islam MA, et al. Molecular characterization and phylogeny of Shiga toxin-producingEscherichia coli isolates obtained from two Dutch regions using whole genomesequencing. Clin Microbiol Infect 2016; (22): 642.e1-642.e9.

37. Nijhuis RH, Oueslati S, Zhou K, Bosboom RW, Rossen JW, Naas T, et al. OXY-2-15, a novel variant showing increased ceftazidime hydrolytic activity. J Antimicrob Chemother. 2015; (70): 1429-33

38. Hasman H, Saputra D, Sicheritz-Ponten T, Lund O, Svendsen CA Frimodt-Moller $\mathrm{N}$, et al. Rapid whole-genome sequencing fordetection and characterization of microorganisms directly from clinicalsamples. J Clin Microbiol 2014; (52): 139-46.

39. Patel JB. 16S rRNA gene sequencing for bacterial pathogen identification inthe clinical laboratory. Mol Diagn. 2001; (6): 313-21.

40. Schuurman T, de Boer RF, Kooistra-Smid AM, van Zwet AA Prospectivestudy of use of PCR amplification and sequencing of $16 \mathrm{~S}$ ribosomal DNA fromcerebrospinal fluid for diagnosis of bacterial meningitis in a clinical setting. J Clin Microbiol. 2004; (42): 734-40.

41. Srinivasan L, Pisapia JM, Shah SS, Halpern CH, Harris MC Canbroad-range 16S ribosomal ribonucleic acid gene polymerase chain reactionsimprove the diagnosis of bacterial meningitis? A systematic review andmeta-analysis. Ann Emerg Med. 2012; (60): 609-20.

42. Kalia VC, Kumar R, Kumar P, Koul S. A genome-wide profiling strategy asan aid for searching unique identification biomarkers for Streptococcus. Indian J Microbiol. 2016; (56): 46-58.

43. Sabat AJ, van Zanten E, Akkerboom V, Wisselink G, van Slochteren K, de Boer RF. Targetedamplification for bacterial identification at the species-level usingnextgeneration sequencing-increased discrimination of closely relatedspecies. ECCMID. 2016; E-poster EP0219.

44. Daubin V, Gouy M, Perriere G. Bacterial molecular phylogeny usingsupertree approach. Genome Inform. 2001; (12): 155-64.

45. Thompson CC, Chimetto L, Edwards RA, Swings J, Stackebrandt E, Thompson FL. Microbial genomic taxonomy. BMC Genom. 2013; (14): 913.

46. Tenover FC, Arbeit RD, Goering RV. How to select and interpretmolecular strain typing methods for epidemiological studies of bacterialinfections: a review for healthcare epidemiologists. Molecular Typing WorkingGroup of the Society for Healthcare Epidemiology of America. Infect Control Hosp Epidemiol. 1997; (18): 426-39.

47. Sabat AJ, Budimir A, Nashev D, Sa-Leao R, van Dijl J, Laurent $F$, et al. Overview of molecular typing methods for outbreakdetection and epidemiological surveillance. Euro Surveil. 2013; (18): 20380.

48. Harrison EM, Paterson GK, Holden MT, Larsen J, Stegger M, Larsen AR, et al. Whole genomesequencing identifies zoonotic transmission of MRSA isolates with the novelmecA homologue mecC. EMBO Mol Med. 2013; (5): 509-15.

49. Макаров В. В., Хромов А. В., Гущин В. А., Ткачук А. П. Возникновение новых инфекций в 21 веке и способы их идентификации с использованием высокопроизводительного секвенирования (NGS). Вестник РГМУ. 2017; (1): 5-25.

50. Яковлев С. В., Суворова М. П. , Белобородов В. Б., Басин Е. Е., Елисеева Е. В., Ковеленов С. В. и др. Распространенность и клиническое значение нозокомиальных инфекций в лечебных учреждениях России: исследование ЭРГИНИ. Антибиотики и химиотерапия 2016; 61 (5-6): 32-42.

51. Козлов Р. С. Пневмококки: уроки прошлого - взгляд в будущее. Смоленск: MAKMAX; 2010.

52. Paterson DL, Rossi F, Baquero F, et al. In vitro susceptibilities of aerobic and facultative Gram-negative bacilli isolated from patient with intra-abdominal infections worldwide: the 2003 Study for Monitoring Antimicrobial Resistance Trend (SMART). J Antimicrob Chemother. 2005; (55): 965-73.

53. Научный отчет о результатах исследования антибиотикорезистентности бактериальных возбудителей нозокомиальных инсекций в отделениях с интенсивным использованием антибиотиков в стационарах России (РеВАНШ). Смоленск: Научно-исследовательский институт антимикробной химиотерапии; 2009

54. Bonomo RA, Burd EM, Conly J, Limbago BM, Poirel L, Segre JA Westblade LF. Carbapenemase-Producing Organisms: A Global Scourge. Clin Infect Dis. 2017 Oct 16.

55. Kohler PP, Volling C, Green K, Uleryk EM, Shah PS, McGeer A. Carbapenem Resistance, Initial Antibiotic Therapy, and Mortality in Klebsiella pneumoniae Bacteremia: A Systematic Review and Meta-Analysis. Infect Control Hosp Epidemiol. 2017 Nov; 38 (11): 1319-28.

56. Zavascki AP, Barth AL, Gaspareto PB, et al. Risk factors for nosocomial infections due to Pseudomonas aeruginosa producing metallo-beta-lactamase in two tertiary-care teaching hospitals. J Antimicrob Chemother. 2006; (58): 882-5.

57. Messadi AA, Lamia T, Kamel B, et al. Association between antibiotic use and changes in susceptibility patterns of $P$. aeruginosa in an intensive care unit: a 5-year study, 20002004. Burns. 2008; (34):1098-102.

58. Яковлев С. В., Проценко Д. Н., Шахова Т. В. и др. Антибиотикорезистентность в стационаре: контролируем ли мы ситуацию? Антибиотики и химиотерапия. 2010; 55 (1-2): 50-58

59. Tacconelli E, De Angelis G, Cataldo MA, et al. Does antibiotic exposure increase the risk of methicillinresistant Staphylococcus aureus (MRSA) isolation? A systematic review and meta-analysis. J Antimicrob Chemother. 2008; (61): 26-38.

60. Sarma JB, Ahmed GU. Characterisation of methicillin resistant S. aureus strains and risk factors for acquisition in a teaching hospital in northeast India. Indian J Med Microbiol. 2010; (28): 127-9.

61. Fair RJ, Tor Y. Antibiotics and bacterial resistance in the 21st century. Perspect Med Chem. 2014; (6): 25-64.

62. Curcio D. Multidrug-resistant Gram-negative bacterial infections: are you ready for the challenge? Curr Clin Pharmacol. 2014; (9): 27-38.

63. De Angelis GD, D'Inzeo T, Fiori B, et al. Burden of antibiotic resistant Gram-negative bacterial infections: evidence and limits. J Med Microbiol Diagn. 2014; (3): 132-37.

64. Глобальный план действий по борьбе с устойчивостью к противомикробным препаратам. ВОЗ. 2016 г. 7 с. Доступно по ссылке: http://apps.who.int/gb/ebwha/pdf_files/WHA69/ A69_24-ru.pdf

65. Яковлев С. В., Проценко Д. Н., Шахова Т. В. и др. Антибиотикорезистентность в стационаре: контролируем ли мы ситуацию? Антибиотики и химиотерапия. 2010; 55 
(1-2): 50-8.

66. Яковлев С. В., Сидоренко С. В., Рафальский В. В., Спичак Т. В., редакторы. Стратегия и тактика рационального применения антимикробных средств в амбулаторной практике. Российские практические рекомендации. М.: Издательство «Пре100принт»; 2014. 121 с.

67. Blair JM, Webber MA, Baylay AJ, et al. Molecular mechanisms of antibiotic resistance. Nat Rev Microbiol. 2015; (13): 42-51.

68. The Protocol for the Prohibition of the Use in War of Asphyxiating, Poisonous or Other Gases, and of Bacteriological Methods of Warfare. United Nations (1925). Available from: http://www. un.org/disarmament/WMD/Bio/1925GenevaProtocol.shtml (last accessed 12 December 2015).

69. World Health Organization. Public health response to biological and chemical weapons - WHO guidance, 2nd edn. Geneva: WHO, 2004.

70. Nuclear Threat Initiative. Available from: http://www.nti.org/ country-profiles (last accessed 12 December 2015).

71. Atlas RM. The medical threat of biological weapons. Crit Rev Microbiol. 1998; (24): 157-68.

72. Leitenberg M, Zilinskas RA, editors. The Soviet biological weapons program: a history. Cambridge, MA: Harvard University Press; 2012.

73. Centers for Disease Control and Prevention. Webpage Emergency Preparedness and Response. Specific hazards: Bioterrorism. Available from: http://www.bt.cdc.gov/ bioterrorism (last accessed 12 December 2015).

74. Carus WS. Bioterrorism and biocrimes: the illicit use of biological agents since 1900. February 2001 revision. Washington, DC: Center for Counterproliferation Research, National Defense University. 2001. Available from: http://www.fas.org/irp/ threat/cbw/carus.pdf (last accessed 12 December 2015).

75. Ackermann GA, Moran KS. Bioterrorism and threat assessment. Weapons of Mass Destruction Commission. 2004. Available from: www.blixassociates.com/wp-content/
uploads/2011/03/No22.pdf (last accessed 12 December 2015).

76. Dando M. Bioterrorism: what is the real threat? Science and Technology Report No. 3. UK Global Health Policy Programme. London: The Nuffield Trust, 2005.

77. Kolavic SA, Kimura A, Simons SL, et al. An outbreak of Shigella dysenteriae Type 2 among laboratory workers due to intentional food contamination. JAMA. 1997; (278): 396-8.

78. Wheelis M, Casagrande R, Madden LV. Biological attack on agriculture: low-tech, high-impact bioterrorism. Bioscience. 2002; (52): 569-76.

79. Bourn J. The 2001 Outbreak of Foot and Mouth Disease. Report by the Comptroller and Auditor General, HC 939 Session 2001-2002. London, UK, National Audit Office. 2002. Available from: www.nao.gov.uk (last accessed 12 December 2015).

80. Meuwissen MPM, Van Boven M, Hagenaars TJ, et al. Predicting future costs of high-pathogenicity avian influenza epidemics: large versus small uncertainties. NJAS. 2006; (52): 195-205.

81. Schmitt K, Zacchia NA. Total decontamination cost of the anthrax letter attacks. Biosecur Bioterror. 2012; (10): 1-10.

82. Gibson DG1, Glass JI, Lartigue C, Noskov VN, Chuang RY, Algire MA, et al. Creation of a bacterial cell controlled by a chemically synthesized genome. Science. 2010 Jul 2; 329 (5987): 52-6. DOI: 10.1126/science.1190719.

83. Gibson DG, Venter JC. Synthetic biology: Construction of a yeast chromosome. Nature. 2014 May 8; 509 (7499): 168-9. DOI: 10.1038/509168a

84. Hutchison CA, Chuang RY, Noskov VN, Assad-Garcia N, Deerinck $\mathrm{TJ}$, Ellisman $\mathrm{MH}$, et al. Design and synthesis of a minimal bacterial genome. Science. 2016 Mar 25; 351 (6280): aad6253. DOI: 10.1126/science.aad6253.

85. Boles KS, Kannan K, Gill J, Felderman M, Gouvis H, Hubby B, et al. Digital-to-biological converter for on-demand production of biologics. Nature Biotechnology. 2017; (35): 672-5. 